FY12 Report: Meteorological

Observations for Renewable Energy Applications at Site 300

S. Wharton, M. Alai, C. Gellner, K. Meyers

October 11, 2012 
This document was prepared as an account of work sponsored by an agency of the United States government. Neither the United States government nor Lawrence Livermore National Security, LLC, nor any of their employees makes any warranty, expressed or implied, or assumes any legal liability or responsibility for the accuracy, completeness, or usefulness of any information, apparatus, product, or process disclosed, or represents that its use would not infringe privately owned rights. Reference herein to any specific commercial product, process, or service by trade name, trademark, manufacturer, or otherwise does not necessarily constitute or imply its endorsement, recommendation, or favoring by the United States government or Lawrence Livermore National Security, LLC. The views and opinions of authors expressed herein do not necessarily state or reflect those of the United States government or Lawrence Livermore National Security, LLC, and shall not be used for advertising or product endorsement purposes.

This work performed under the auspices of the U.S. Department of Energy by Lawrence Livermore National Laboratory under Contract DE-AC52-07NA27344. 


\section{FY12 Report: Meteorological observations for renewable energy applications at Site 300}

Project team for measurements: Sonia Wharton, Maureen Alai, Cary Gellner, and Katie Myers

\section{Introduction}

Accurate, high-resolution meteorological measurements of wind flow in the planetary boundary layer (PBL) and surface-atmosphere energy exchange are required for understanding the properties and quality of available wind power at Site 300 . Wind speeds at heights found in a typical wind turbine rotor disk ( 40-120 m) are driven by the synergistic impacts of atmospheric stability, orography, and landsurface characteristics on the mean wind flow and related turbulence structures in the PBL. In FY11, two Laser and Detection Ranging (LIDAR) units, a $3 \mathrm{~m}$ tall flux tower, and a $3 \mathrm{~m}$ tall meteorological tower were installed in the northern section of Site 300 as a first step in development of a renewable energy testbed facility. The LIDAR units were programmed to measure wind speed and direction up to $200 \mathrm{~m}$. The flux tower measured land surface-atmospheric energy exchanges and provided information on the mechanisms for turbulence production in the atmosphere and atmospheric stability. Atmospheric stability largely determines wind speed and turbulence profiles in the lower part of the boundary layer where wind turbines reside.

In FY12 the SMS project was further expanded by the earlier addition of solar power to the LIDAR units. This enabled the units to be moved to different areas within Site 300 in order to gather a larger spatial range of measurements. Additional LIDAR locations were chosen based on (1) feasibility and logistics (e.g., away from the blast zone and special habitat zones) and (2) areas forecasted to have high wind speeds and/or high turbulence from the Weather Research and Forecasting (WRF) model simulations. High turbulence is of interest because very high amounts of turbulent energy can be damaging to turbine components. Between December 2011-April 2012, the two LIDAR units were rotated amongst three locations: the tall $(52 \mathrm{~m})$ meteorological tower, the radio tower, and the Matthew area (named after Matthew Simpson) (Figure 1). The radio tower location was in the center of Site 300 and represented the site with highest elevation and potentially highest wind speeds as forecasted by WRF. The Matthew area in the southeast represented a site with high wind speeds and potentially high levels of turbulence.

In FY11 we presented a quality control report which illustrated the accuracy of the LIDAR wind speed and direction measurements as compared to the $52 \mathrm{~m}$ tall meteorological tower and provided annual statistics for wind speed and direction up to $200 \mathrm{~m}$ for the meteorological tower location in the northern section of Site 300 . In the FY12 report we present:

1. a second year of LIDAR and flux tower statistics for 2012,

2. an enhanced spatial dataset of LIDAR observations with the addition of two new sites, and

3. a look at off-site LIDAR field campaigns. 


\section{Instrumentation and field campaigns}

Table 1 lists the field campaigns completed in FY12 and the planned LIDAR campaign this fall at the Atmospheric Radiation Measurement (ARM) site in Oklahoma. Data collection statistics for FY12 include:

1. 13,500 hours of LIDAR measurements were collected including 5760 hours at Site 300,2784 hours at Buena Vista wind farm (Wayne Miller, PI), and 4992 hours at other field sites including the EERE Wind Forecasting Improvement Project in South Dakota (Jeff Mirocha, PI).

2. 8500 hours of flux tower data were collected at Site 300 . This equals a $96 \%$ data availability rate for energy and carbon fluxes. The data are also used in Sonia Wharton's LDRD project and the Site 300 flux tower are soon to be included in the AmeriFlux carbon flux database housed at ORNL.

\begin{tabular}{|c|c|c|c|c|}
\hline Location & Instrumentation & Latitude & Longitude & Dates \\
\hline \multicolumn{5}{|c|}{ Site 300} \\
\hline $\begin{array}{l}\text { Tall } \\
\text { meteorological } \\
\text { tower }\end{array}$ & LLNL LIDAR & 37.675 & -121.541 & $\begin{array}{l}\text { October 2010- } \\
\text { June 2011, Oct - } \\
\text { Dec 2011, Feb- } \\
\text { March } 2012\end{array}$ \\
\hline Radio tower & LLNL LIDAR & 37.652 & -121.534 & $\begin{array}{l}\text { Dec 2011-March } \\
2012\end{array}$ \\
\hline Matthew area & LLNL LIDAR & 37.648 & -121.502 & March-April 2012 \\
\hline $\begin{array}{l}\text { Flux tower \& } 2 \text { m } \\
\text { meteorological } \\
\text { tower }\end{array}$ & $\begin{array}{l}\text { LLNL sonic anemometer, infrared } \\
\text { gas analyzer, air temp/RH, wind } \\
\text { vane, cup anemometer, soil } \\
\text { moisture/temp., net radiation }\end{array}$ & 37.677 & -121.530 & $\begin{array}{l}\text { October 2010- } \\
\text { present }\end{array}$ \\
\hline \multicolumn{5}{|c|}{ Off-site campaigns } \\
\hline $\begin{array}{l}\text { Buena Vista wind } \\
\text { farm: winter site }\end{array}$ & LLNL LIDAR & 37.800 & -121.663 & $\begin{array}{l}\text { Nov 2011-Jan } \\
2012\end{array}$ \\
\hline $\begin{array}{l}\text { Buena Vista wind } \\
\text { farm: summer site }\end{array}$ & LLNL LIDAR & 37.798 & -121.667 & June-August 2012 \\
\hline $\begin{array}{l}\text { Tonzi AmeriFlux } \\
\text { tower }\end{array}$ & $\begin{array}{l}\text { LLNL LIDAR, LLNL radiosondes, \& } \\
\text { UC Berkeley flux tower }\end{array}$ & 38.432 & -120.971 & April 2012 \\
\hline $\begin{array}{l}\text { Wind River } \\
\text { AmeriFlux tower }\end{array}$ & $\begin{array}{l}\text { LLNL LIDAR, LLNL radiosondes, \& U. } \\
\text { of Washington flux tower }\end{array}$ & 45.816 & -121.951 & May 2012 \\
\hline $\begin{array}{l}\text { WFIP, De Smet, S. } \\
\text { Dakota }\end{array}$ & $\begin{array}{l}\text { LLNL LIDAR, NOAA wind profilers, } \\
\text { NOAA SODAR }\end{array}$ & 44.432 & -97.556 & $\begin{array}{l}\text { June -Oct 2011, } \\
\text { April -Aug } 2012\end{array}$ \\
\hline $\begin{array}{l}\text { Southern Great } \\
\text { Plains ARM }\end{array}$ & $\begin{array}{l}\text { LLNL LIDAR, OU Halo Doppler } \\
\text { LIDAR, DOE wind profilers, DOE } \\
\text { radiosondes, LBL flux tower }\end{array}$ & 36.605 & -97.485 & $\begin{array}{l}\text { planned for Fall } \\
2012\end{array}$ \\
\hline
\end{tabular}

Table 1: Site locations and campaign dates for the Site 300 observational network as well as the off-site LIDAR campaigns. 


\section{2a. Site 300 atmospheric observations network}

The atmospheric network at Site 300 includes the LIDARs, flux tower and meteorological towers for gathering meteorological observations up to $200 \mathrm{~m}$. The LIDARs were programmed to measure wind speed and direction at a sampling rate of $1 \mathrm{~Hz}$ from 40-200 $\mathrm{m}$ above the surface at $20 \mathrm{~m}$ vertical resolution. Turbulence characteristics were derived from $1 \mathrm{~Hz}$ data and included turbulence intensity and turbulence kinetic energy (TKE). TKE is a direct measure of the magnitude of turbulence. $1 \mathrm{~Hz}$ data were also averaged over 10 minute periods to obtain mean horizontal and vertical wind speed and mean wind direction. Energy fluxes of sensible heat $(H)$, latent heat $(L E)$ (i.e., evapotranspiration), and ground heat flux were taken at the flux tower using a sonic anemometer, infrared gas analyzer and soil temperature profile system. Atmospheric fluxes were sampled at a rate of $1 \mathrm{~Hz}$ and were calculated using the eddy covariance method with a 30-minute averaging period, horizontal coordinate rotation, and the Webb-Pearman-Leuning corrections. Additional measurements included soil moisture, net radiation, air temperature, relative humidity, and air pressure at 30-min averaged intervals.

At Site 300 , the terrain is primarily dominated by ridge lines which run northwest-to-southeast with elevations along the ridges from 360 to $500 \mathrm{~m}$ a.s.I. The terrain surrounding the Matthew location is some of the most complex found at Site 300 and the area is surrounded to the north and east by a steep canyon (Elk Ravine) and to the west by a steep ridge.

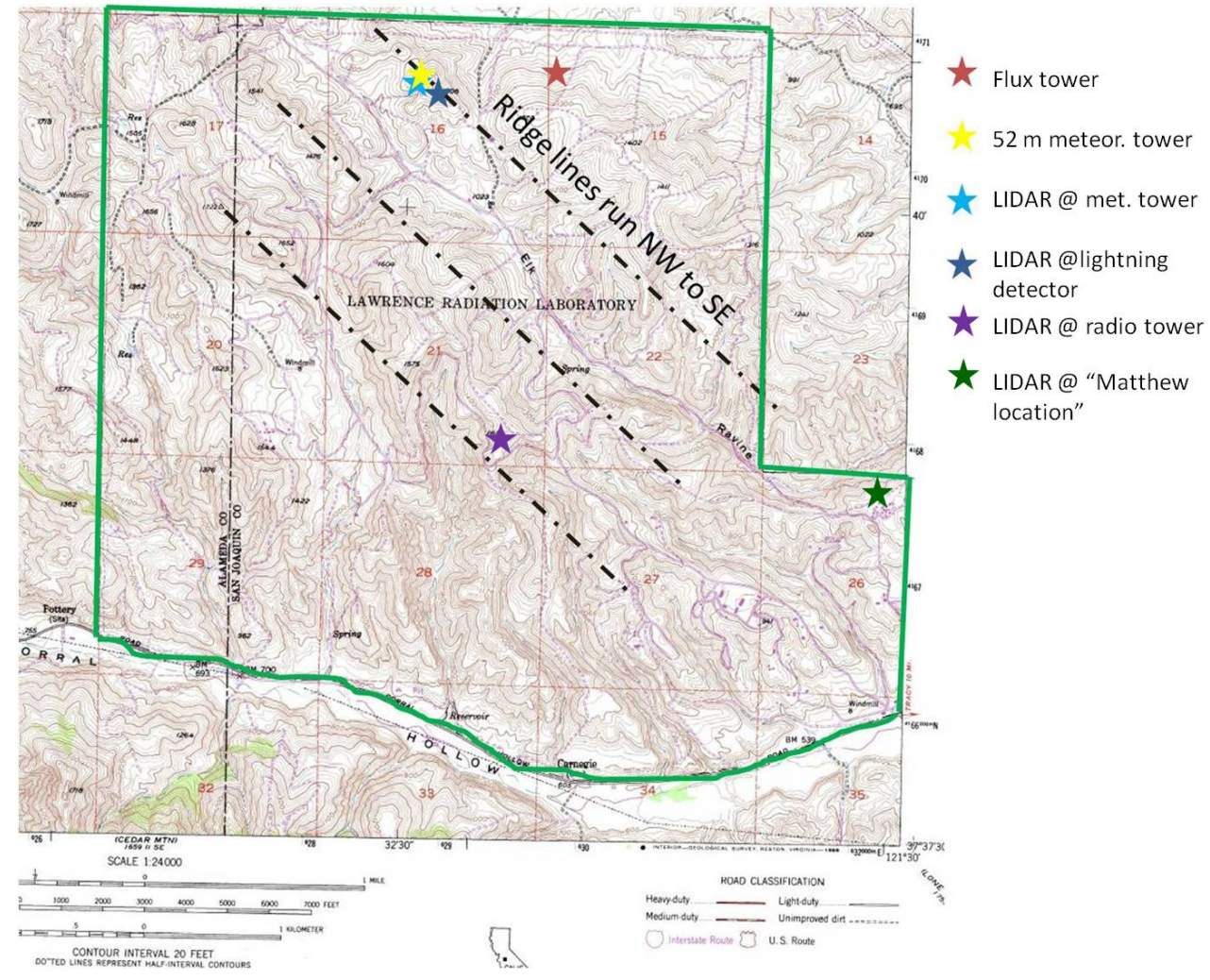

Figure 1: USGS topographical map of Site 300 showing the locations of the atmospheric instrument network including the flux tower, $52 \mathrm{~m}$ tall meteorological tower and locations of the LIDARs at the meteorological tower, lightning detector, radio tower and "Matthew location". Also shown are the dominant ridge lines (dashed lines) which run northwest-to-southeast across a large section of Site 300. 


\section{2b. Off-site LIDAR field campaigns}

The goal of the SMS project was to build the capability at LLNL for conducting high-resolution atmospheric measurements for wind energy and other applications. This goal was met, starting from the initial LLNL purchase of two LIDAR units and deployment of a flux tower at Site 300 in 2010, to the five LIDAR field locations in FY12. These instruments have been used thus far for two LDRD projects and an off-site EERE-NOAA-WindLogics project. The projects utilized LIDAR wind speed, direction and turbulence data for a number of applications including quantifying inflow turbine wind conditions at the Buena Vista wind farm, capturing turbulence and wind shear characteristics over plant canopies at the Wind River and Tonzi Ameriflux towers, and making measurements of lower boundary layer wind speed and direction measurements in South Dakota for improving wind forecasting models. An additional field campaign has been planned for the Southern Great Plains ARM site to test the accuracy of LIDAR turbulence measurements against sonic anemometer-equipped tall towers. A map of the LIDAR field campaign sites is below.

\section{LLNL LIDAR field campaigns}

t. Wind River AmeriFlux

负 Tonzi Ameriflux

Ar Buena Vista wind farm

Site 300 (multiple sites)

\section{South Dakota WFIP}

Southern Great Plains ARM

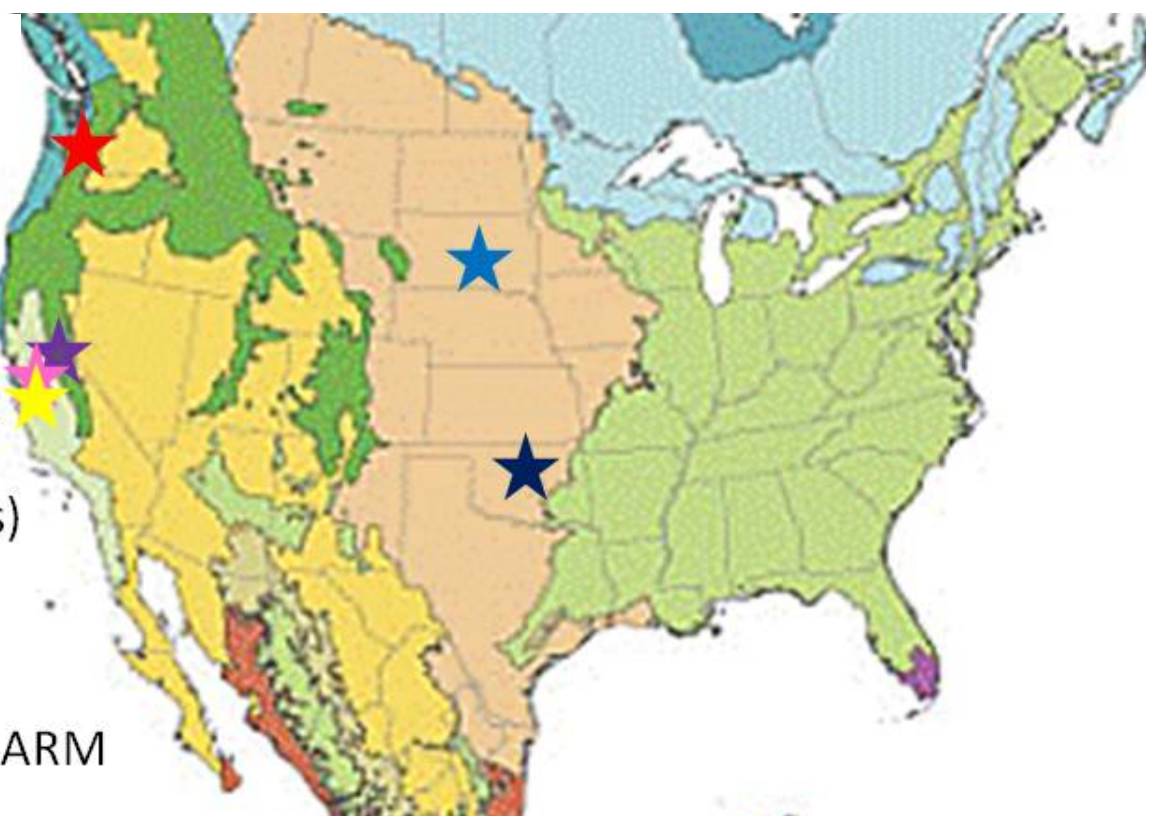

Figure 2: Ecoregion map of North American with the LLNL LIDAR field campaigns up to 2012. Wind power related projects include: Site 300 and Buena Vista Wind Farm in California, the EERE-NOAAWindLogics Wind Forecasting Improvement Project (WFIP) in South Dakota and the upcoming deployment to the DOE's Southern Great Plains Atmospheric Radiation Measurement (ARM) Program. Plant canopy flow and biospheric flux studies include Site 300, the Tonzi AmeriFlux tower (UC Berkeley) in the California, and the Wind River Ameriflux tower (University of Washington) in southern Washington state. 


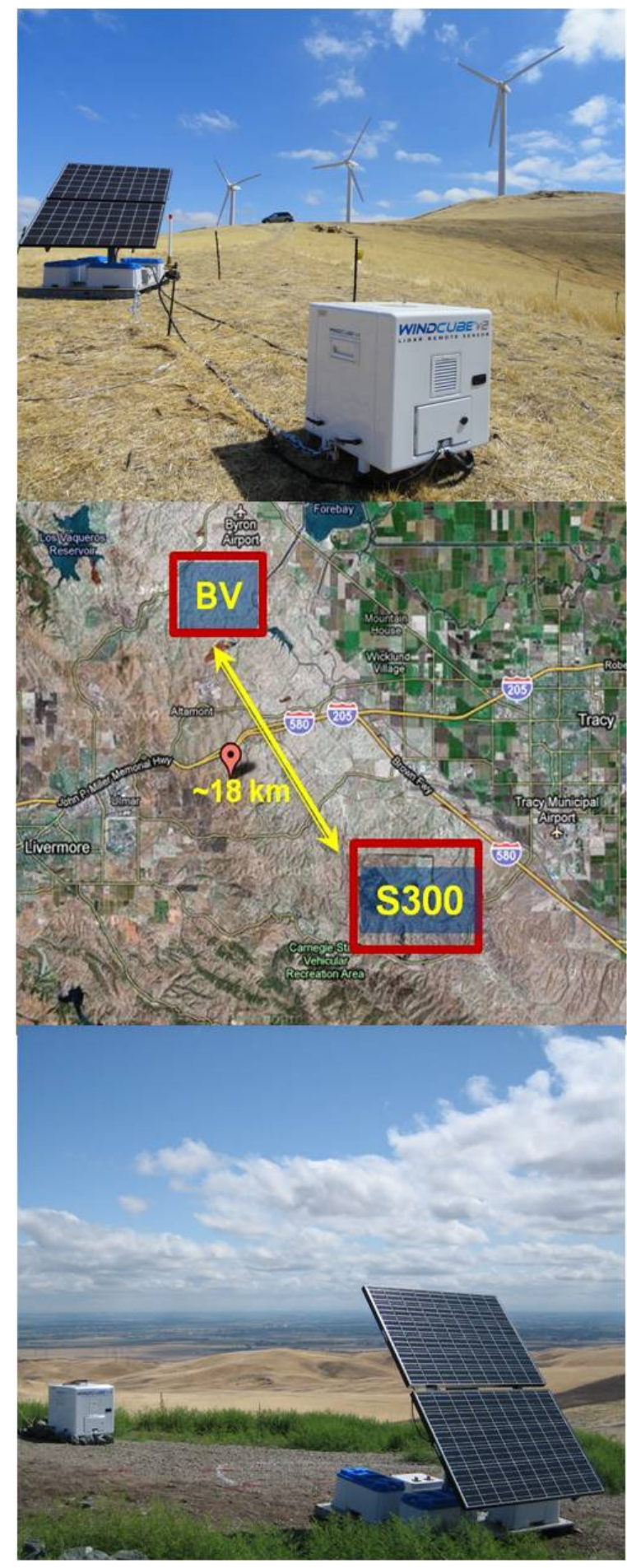

Figure 3: The LIDAR units were included in a LDRD project, "Forecasting and UQ of power from intermittent renewable energy sources" to measure the inflow wind speed, direction and turbulence conditions at the Buena Vista Wind Farm near Byron, CA (top panel). The wind farm is in the Altamont Pass region of California and is $18 \mathrm{~km}$ northwest of Site 300 (lower panel). Both locations have complex topography and are annual grasslands. More information about Buena Vista can be found at: http://www.infigenenergy.com/ 


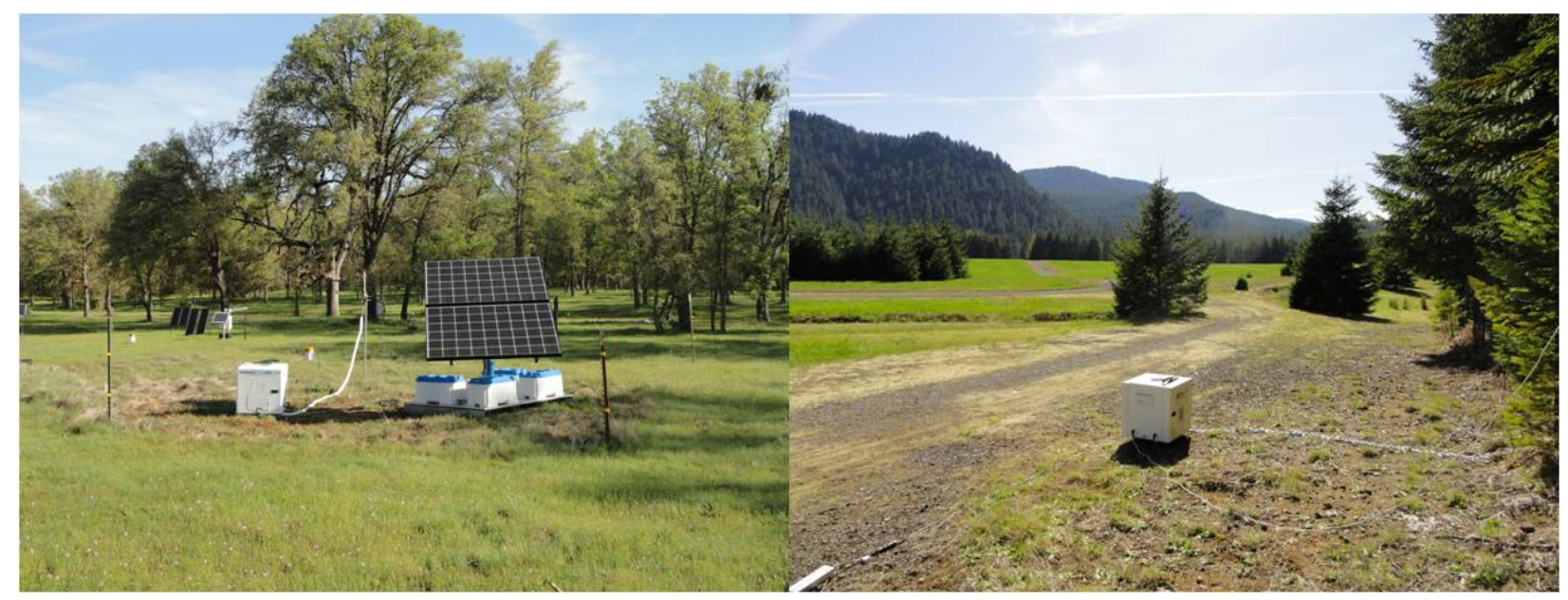

Figure 4: LIDAR units were used in a second LDRD project, "A new method for reducing the uncertainty in biospheric $\mathrm{CO} 2$ flux". The LIDARs were utilized in this project to better understand flow features over plant canopies including the nature and origin of turbulence with the goal of increasing the accuracy of the biospheric carbon flux estimate from a measurement-land surface model integration. Field campaigns included the Tonzi AmeriFlux tower location near lone, CA in an oak savannah (left) and the Wind River AmeriFlux tower site in the Gifford Pinchot National Forest, WA (right). For more information about the AmeriFlux network: http://ameriflux.ornl.gov/sitelocations.php

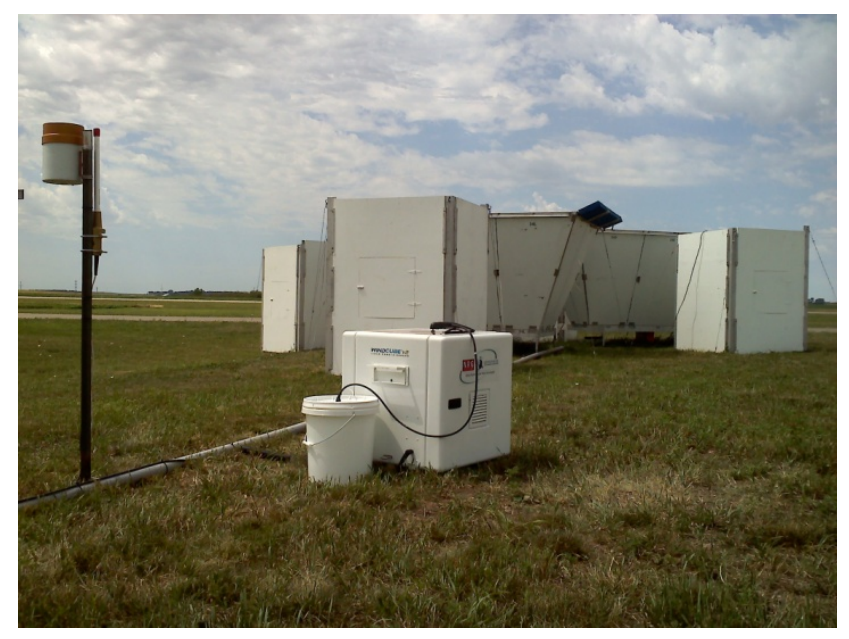

Figure 5: LLNL's LIDAR provided valuable lower boundary layer measurements for the Wind Forecasting Improvement Project in De Smet, South Dakota. The LODAR was co-located with NOAA's Radioacoustic Sounding System (RASS-Doppler Wind Profiler + SODAR) which provided temperature and higheraltitude wind speed profiles. For more information: http://www.esrl.noaa.gov/psd/psd3/wfip/ 


\section{Results}

\section{LIDAR and flux tower data quality control measures}

At Site 300, the LIDAR units, flux tower and 2 m meteorological tower were visited weekly for instrument inspection and data download. At this time, the instruments and wiring were checked for animal damage, such as animals chewing on wires or bird droppings on sensors. Voltages were also checked weekly to make sure that power was constant and above $12 \mathrm{~V}$ (flux tower/met tower) or $24 \mathrm{v}$ (LIDARs) from the solar panels. The LIDARs were also checked remotely when the units were in areas with adequate cell phone coverage at NRG's website. LIDAR data were post-processed at LLNL based on the signal-to-noise (CNR) ratio and the data availability \%. We chose to use more stringent quality control thresholds than NRG applies to the data via its data processing software. This included removing 10-minute averages if (1) the average CNR $<-22$ and the data availability was $<25 \%$ for the 10 minute period. The flux data were checked for latent energy and sensible energy outliers which were often due to rain or dew on the sonic sensor heads. These data points were removed.

\section{Multiple LIDAR locations at Site 300}

The radio tower and "Matthew location" were added in FY12 to include measurement points in the central and southeast portions of Site 300 to meet the following goals: (1) improve understanding of terrain-induced flow features across Site 300 and (2) provide additional spatial data for validating Site 300 WRF runs. The two LIDARs were rotated between the meteorological tower, radio tower and Matthew areas in winter and spring of 2012. The LIDAR units at the meteorological tower and radio tower were separated by a distance of $2.6 \mathrm{~m}$; the meteorological tower and Matthew location was separated by a distance of $3.4 \mathrm{~km}$. Overlapping time periods included: February 2-27, 2012 (Meteorological tower and radio tower) and March 12-April 4, 2012 (Matthew area and meteorological tower). The figures in this section show LIDAR wind speed, direction and turbulence intensity measurements for $40 \mathrm{~m}, 80 \mathrm{~m}$ and $120 \mathrm{~m}$. These heights were chosen as they represent typical hub height $(80 \mathrm{~m})$ as well as heights found at the bottom $(40 \mathrm{~m})$ and top $(120 \mathrm{~m})$ of a turbine rotor disk. Also included in the wind velocity plots, is cut-in $(3 \mathrm{~m} / \mathrm{s})$ and rated $(12.5 \mathrm{~m} / \mathrm{s})$ speed for a typical turbine (1 $\mathrm{MW}$ ) in the Altamont Pass.

Normalized wind speed profiles are also shown in this section. Basic boundary layer theory suggests that wind speed increases with height from zero right at the ground surface to higher wind speeds aloft in a logarithmic manner, depending on the surface roughness of the land or plant canopy (which create frictional forces at the surface) and the assumption of neutral atmospheric stability. Normalized wind speeds above 1 represent average winds faster than at $80 \mathrm{~m}$ while normalized speeds below 1 show slower wind speeds. The logarithmic wind profile was calculated using Eq. 1 :

$$
\overline{U(z)}=\frac{1}{k} \ln \left(\frac{z+z_{o}}{z_{o}}\right) * u_{*}
$$


Where $k$ is the von Karman constant $(0.4), z_{0}$ is the surface roughness $(m), z$ is the height of interest above the surface $(\mathrm{m})$ and $\mathrm{u}_{*}$ is the frictional or shear velocity $(\mathrm{m} / \mathrm{s})$ near the surface. Here, we used $\mathrm{a}_{\mathrm{o}}$ of $0.03 \mathrm{~m}$ based on the average grassland canopy height of $0.30 \mathrm{~m}$ in the winter at Site 300 . We also used a $u_{*}$ value of $0.3 \mathrm{~m} / \mathrm{s}$ based on an average of $u_{*}$ as measured by the flux tower at $2 \mathrm{~m}$ height for this period. The logarithmic profile assumes a neutral boundary layer and assumes that the height of interest is found within the surface layer (first 100-200 m above ground). Even though these assumptions are frequently invalidated, especially during a stable atmosphere, it is still a useful metric of how far the actual wind profile deviates from the expected norm. Equation 1 was solved for heights equivalent to the LIDAR (40-200 m, $20 \mathrm{~m}$ resolution). In these plots the profile is shown only to a height of $140 \mathrm{~m}$ because of higher data losses at 160 and $200 \mathrm{~m}$.

During the February campaign, the average $80 \mathrm{~m}$ (or typical hub-height) wind speed was above cut-in speed $77 \%$ of the time at the meteorological tower location and $79 \%$ of the time at the radio tower location. The winds were above the rated speed $7 \%$ of the time at both locations.

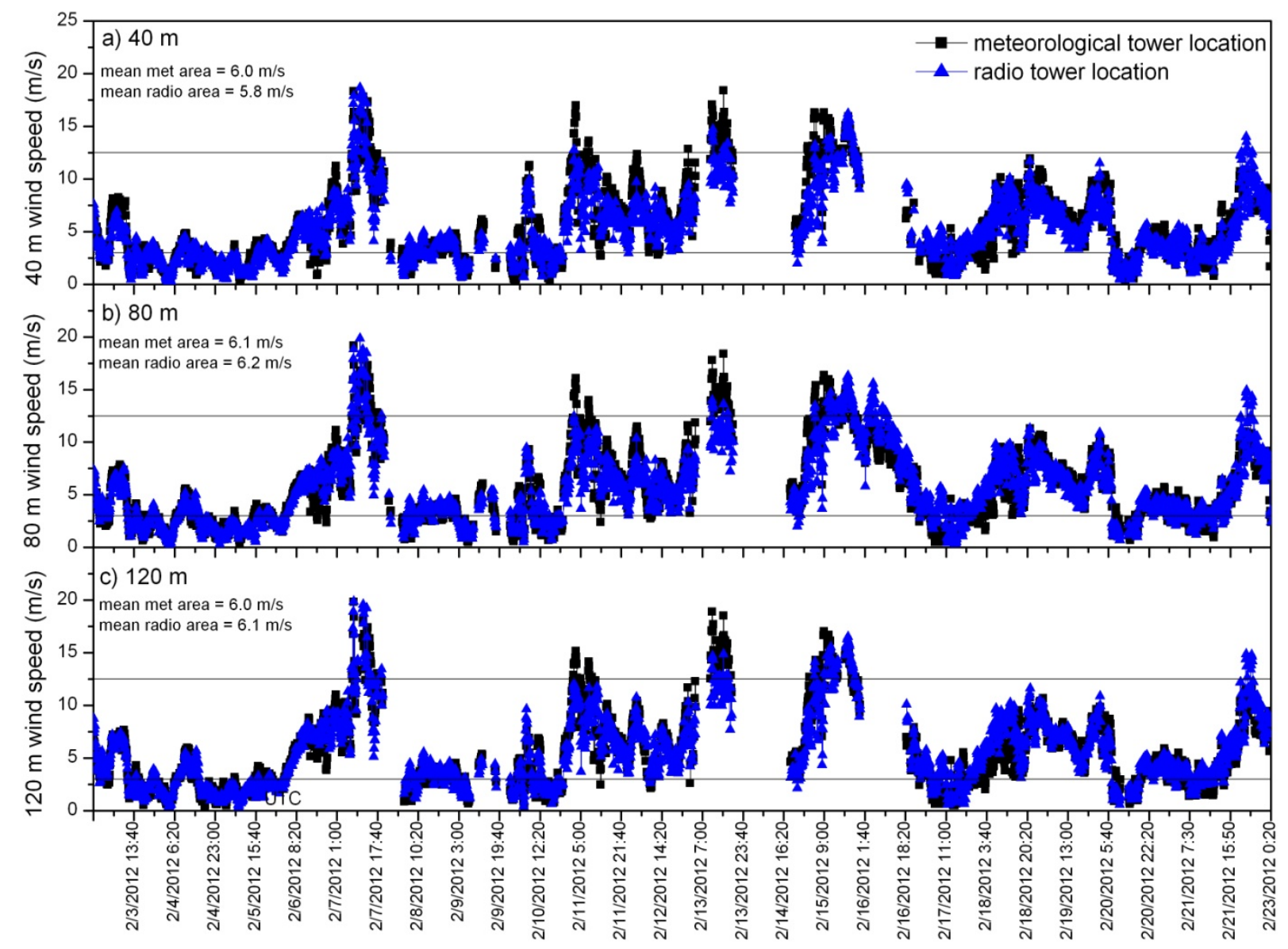

Figure 6: Time series of LIDAR (a) $40 \mathrm{~m}$, (b) $80 \mathrm{~m}$, and (c) $120 \mathrm{~m}$ wind speed at the meteorological tower and radio tower locations. The wind speeds are similar at both locations and average around $6 \mathrm{~m} / \mathrm{s}$ during the month of February. The largest difference between wind speed is at the $40 \mathrm{~m}$ height. The radio tower LIDAR was $2.6 \mathrm{~km}$ south of the meteorological tower location and was in higher terrain. 


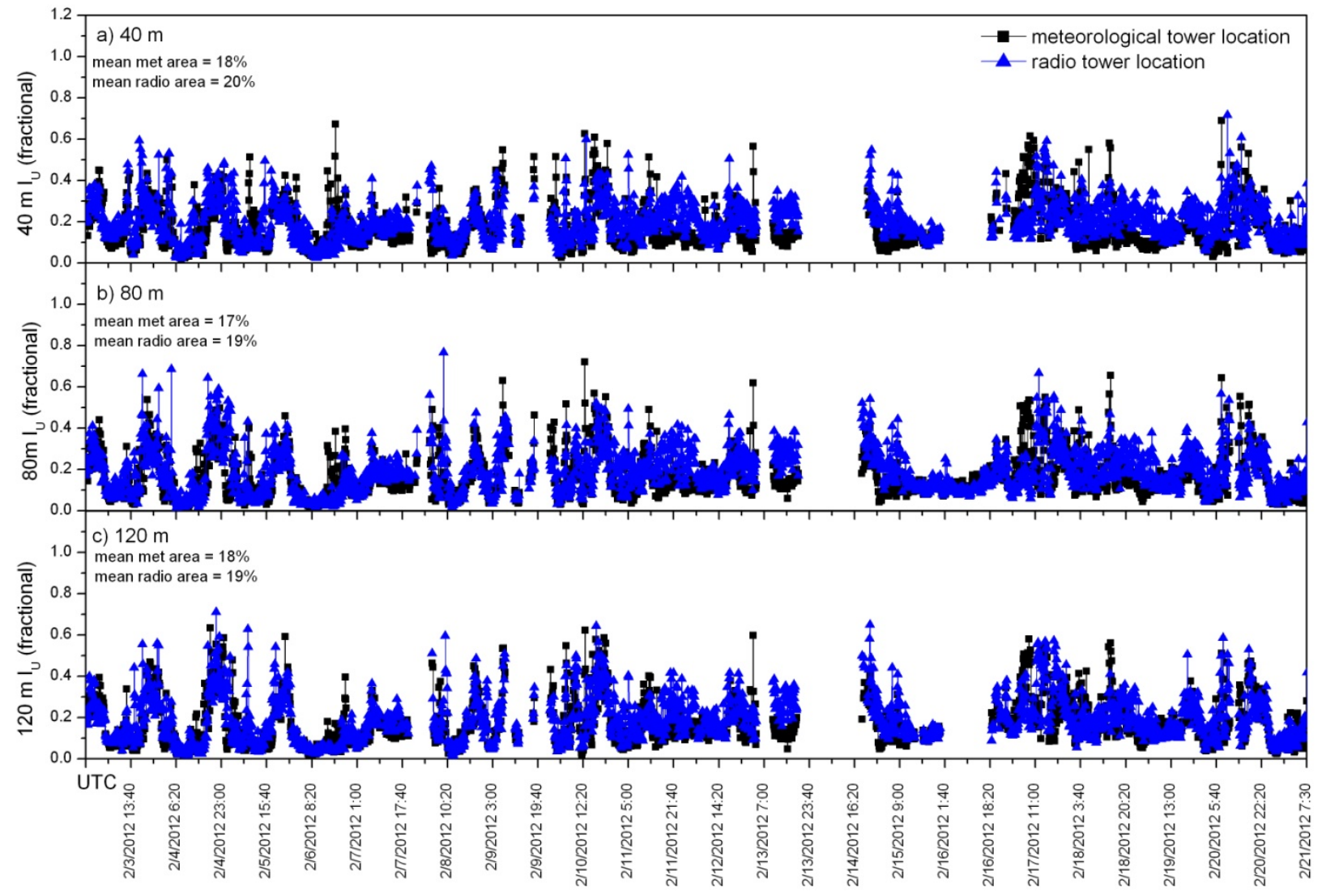

Figure 7: Time series of LIDAR horizontal turbulence intensity $\left(l_{u}\right)$ at (a) $40 \mathrm{~m}$, (b) $80 \mathrm{~m}$, and (c) $120 \mathrm{~m}$ for the meteorological tower and radio tower locations. Turbulence intensity is slightly higher at the radio tower location and reaches an average $20 \%$ at the $40 \mathrm{~m}$ height. 


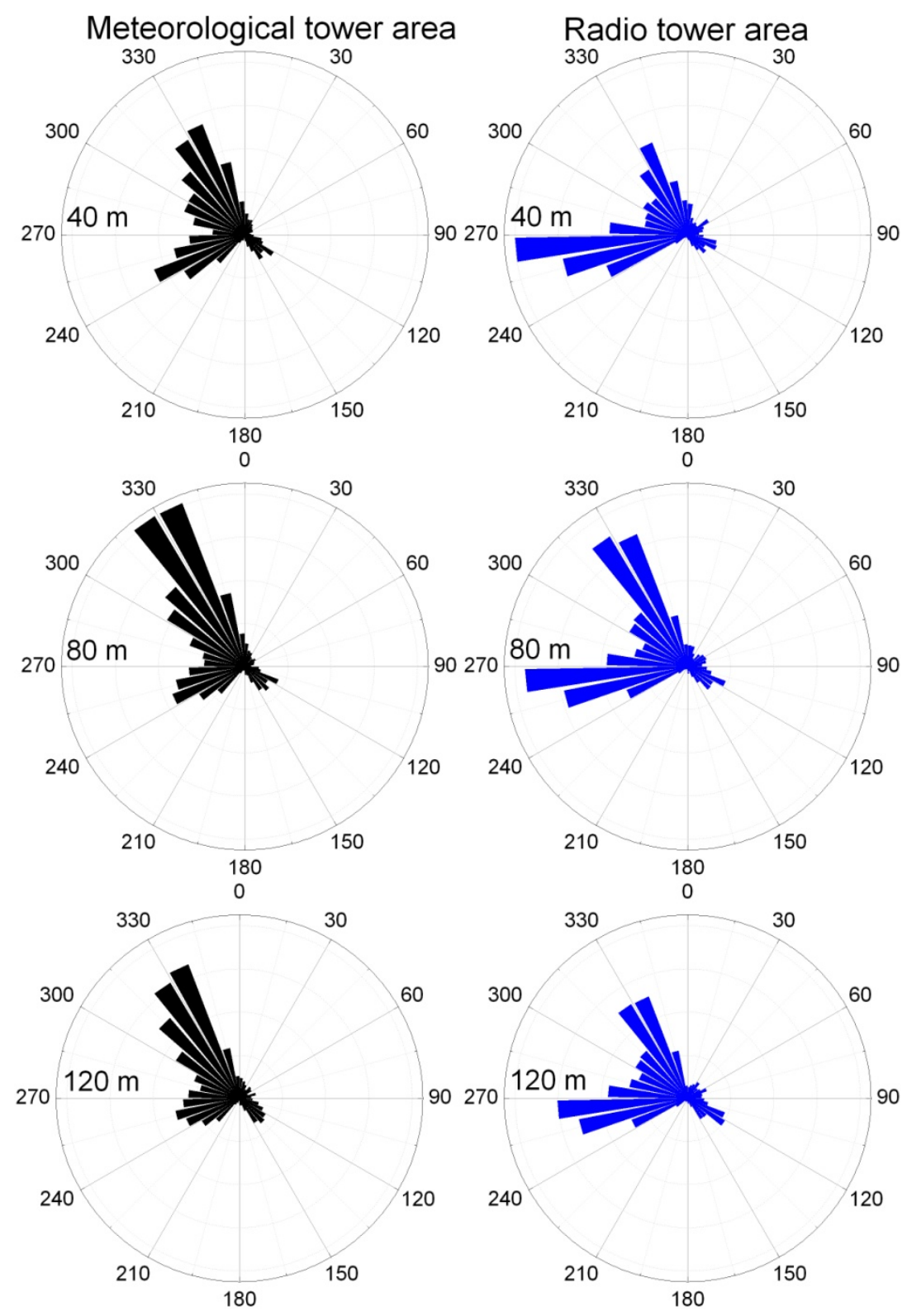

Figure 8: Frequency distributions of LIDAR wind direction at each height at both locations during the February field campaign. The radio tower location experienced more winds from the west than the meteorological tower location. Wind direction shear is more evident at the radio tower location as well as winds shift towards the northwest with height. Northeasterly winds are more common at the meteorology tower location for the same time period. 


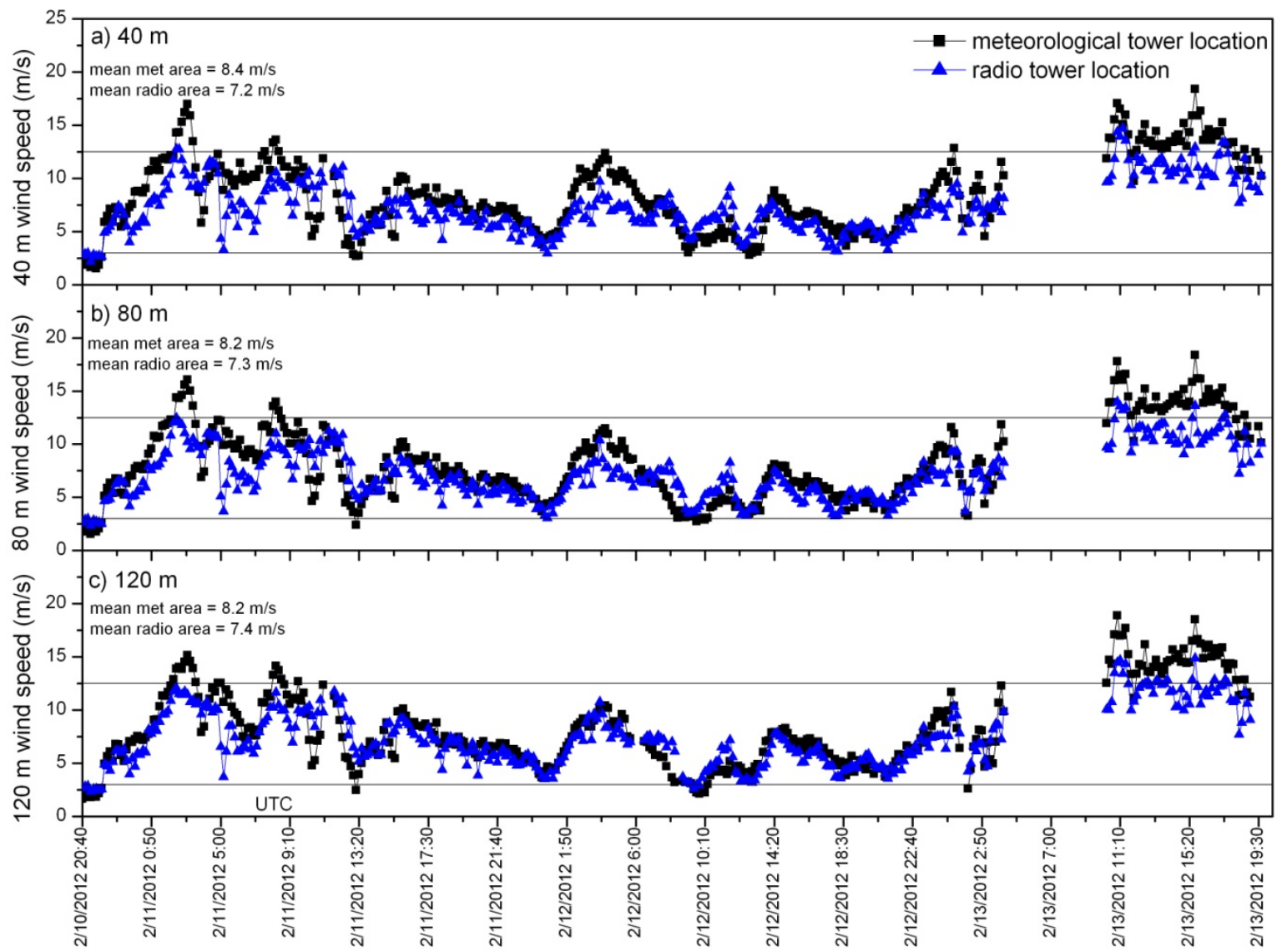

Figure 9: A close-up of two days in February 2012 shows wind speed differences between both locations as the meteorological tower saw overall higher wind velocities of around $1 \mathrm{~m} / \mathrm{s}$. A large difference in the amount of shear is also apparent as the radio tower location experienced a larger degree of positive shear, i.e, wind speed consistently increases with height on these days. Wind speed at the meteorological tower location decreased with height from maxima found at $40 \mathrm{~m}$ during this time period. 


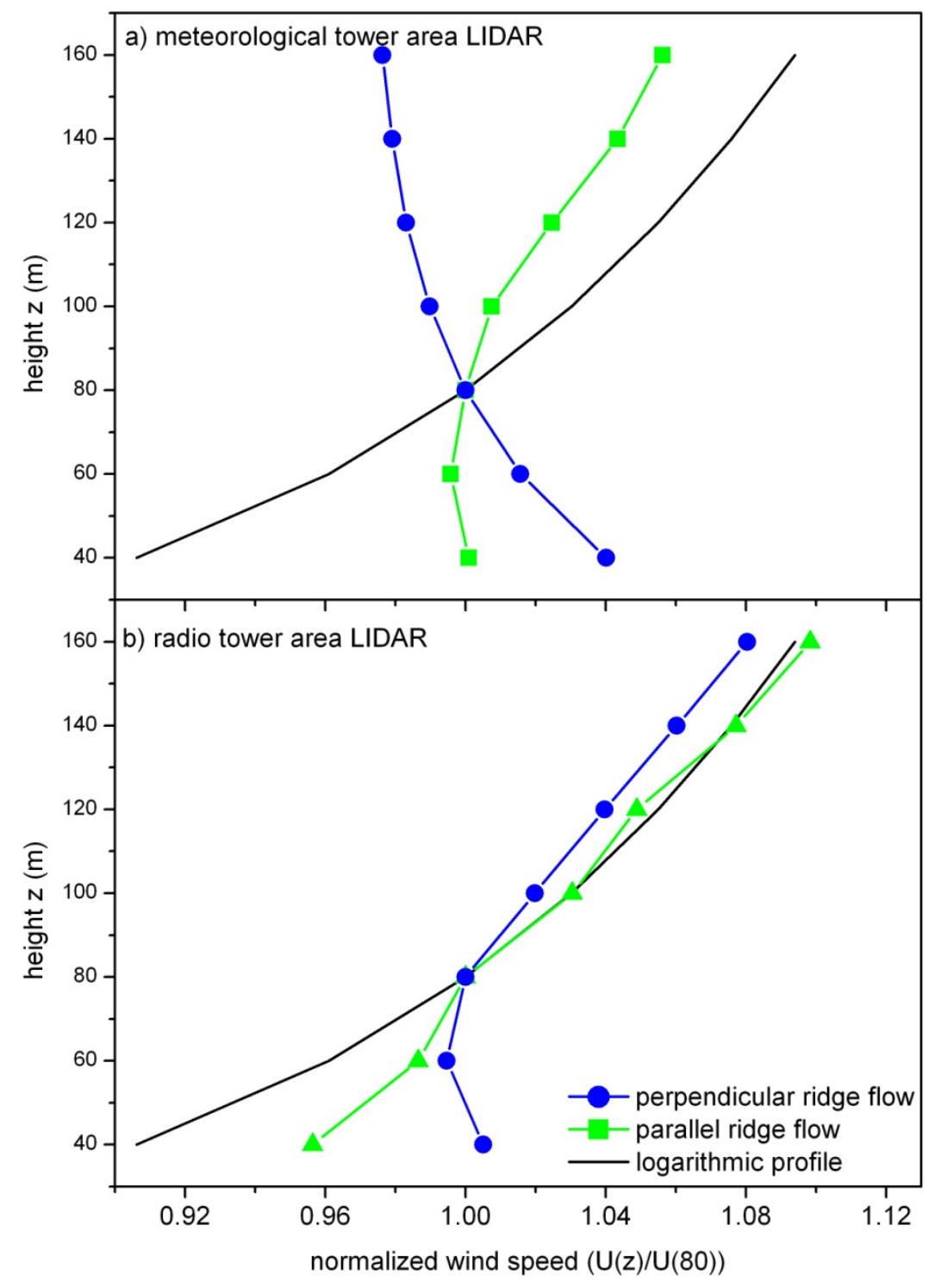

Figure 10: Normalized wind speed profiles from the LIDAR units in February showing wind shear conditions at the meteorological tower and radio tower areas. The wind speed data were segregated by $80 \mathrm{~m}$ wind direction. Perpendicular ridge flows represent winds from the northeast and southwest, parallel ridge flows are winds from the northwest and southeast at both sites. Also plotted is the expected or logarithmic wind profile. At the meteorological site, the wind speed varies dramatically from the predicted profile when winds hit the ridge line perpendicularly. This is similar to findings found in FY11. 
For the spring field campaign, wind speeds were over $75 \%$ of the time above cut-in speed and $10 \%$ of the time above the rated speed at both locations (Figure 11). The time series agree well as there is little to no delay in ramping events between sites even though the Matthew site is $\sim 4.5 \mathrm{~km}$ away in more complex terrain. The largest discrepancies occurs for wind speed magnitude as the average wind speed at hub-height was $6.1 \mathrm{~m} / \mathrm{s}$ at the meteorological tower location and $5.5 \mathrm{~m} / \mathrm{s}$ at the Matthew site.

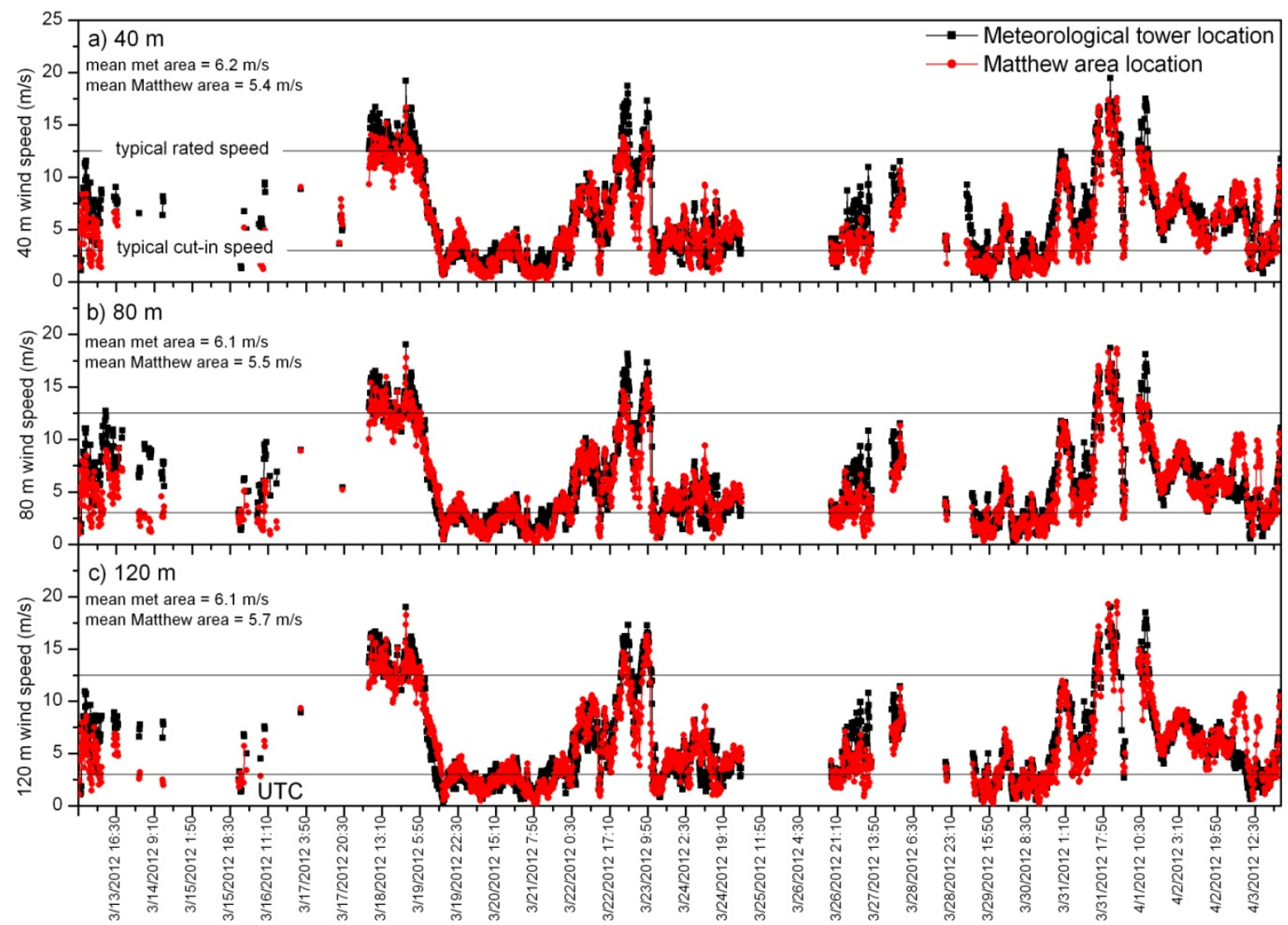

Figure 11: Wind speed at heights of (a) $40 \mathrm{~m}$, (b) $80 \mathrm{~m}$, and (c) $120 \mathrm{~m}$ for the two LIDAR units located at the meteorological tower and at the Matthew location for the overlapping March-April period. Missing data are due to rain. Overall, the wind speed was higher at the meteorological tower location than at the Matthew area although wind shear was greater (more positive) at the second location. 


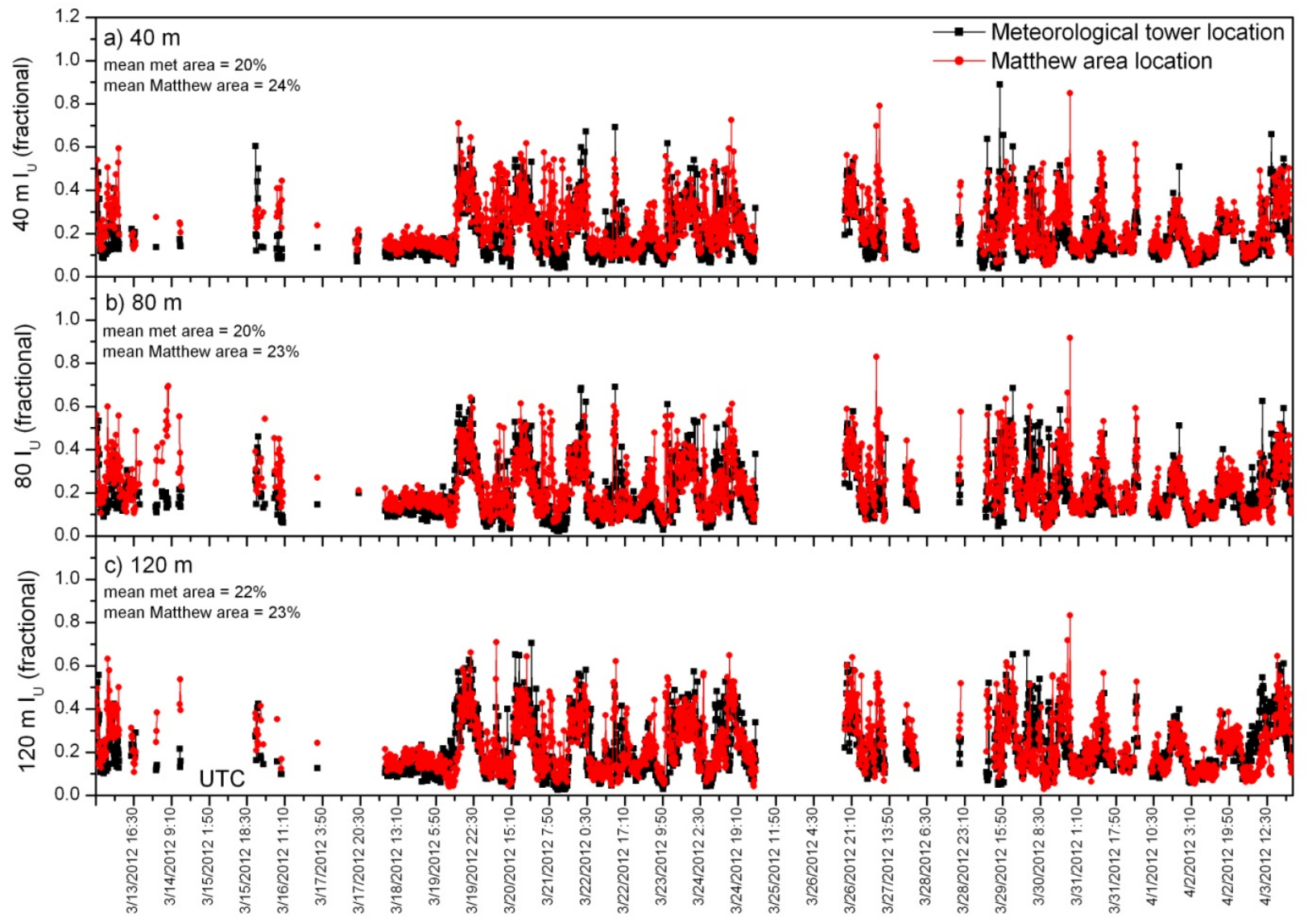

Figure 12: Horizontal turbulence intensity ( $\mathrm{l}_{\mathrm{u}}$ ) at heights of (a) $40 \mathrm{~m}$, (b) $80 \mathrm{~m}$, and (c) $120 \mathrm{~m}$ for the two LIDARs in March-April 2012. Turbulence intensity was on average higher at the Matthew location due to overall lower wind speeds and higher standard deviations from the mean than the meteorological tower location. During this period, turbulence intensity averaged between $20 \%-24 \%$ and was fairly uniform with height. 


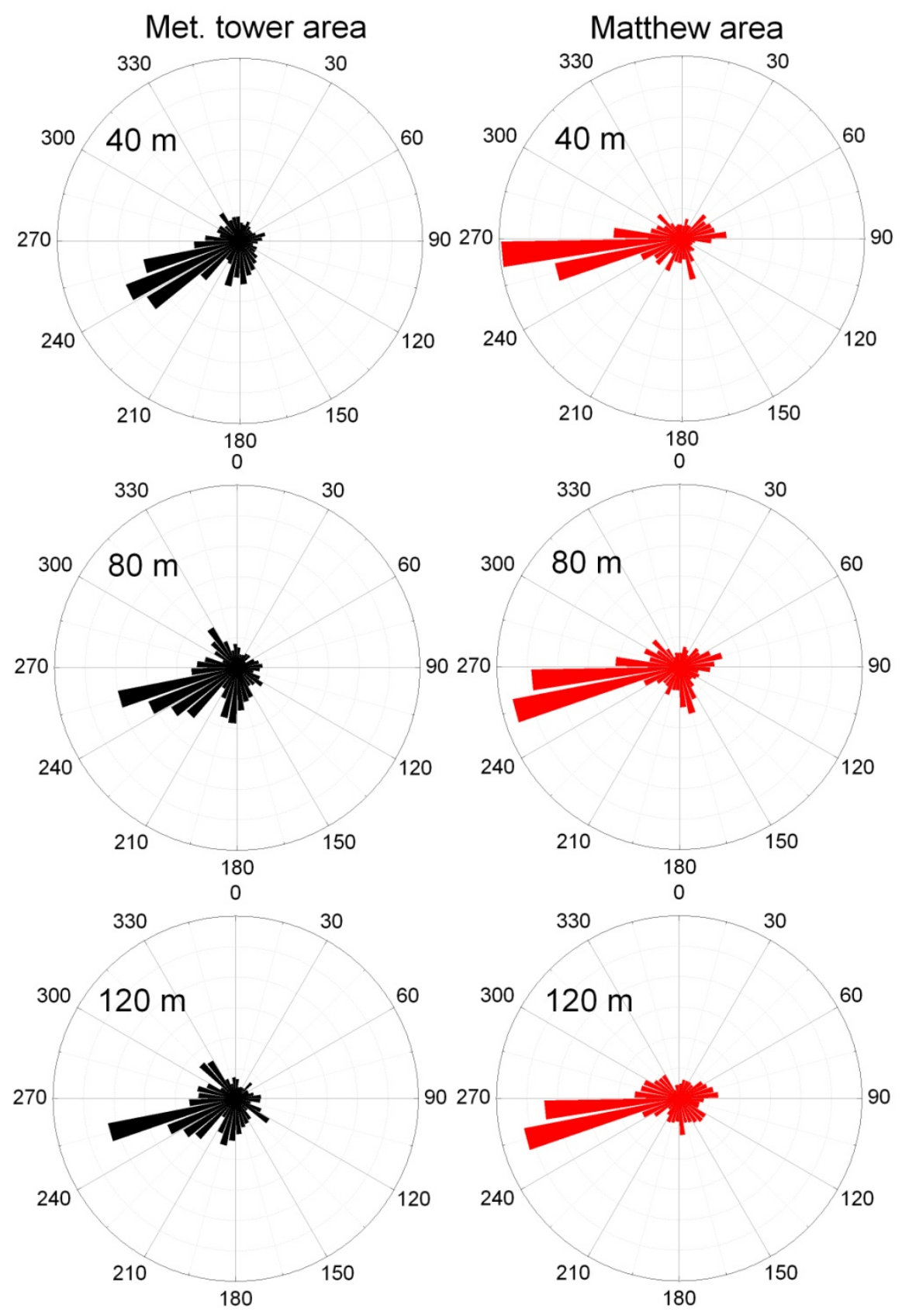

Figure 13: Histograms of wind direction at $40 \mathrm{~m}, 80 \mathrm{~m}$, and $120 \mathrm{~m}$ for both LIDARs in March-April 2012. At the meteorological tower location, the dominant wind direction is from the southwest between 210270 degrees. At the Matthew location, the winds are strongly predominant from the west or westsouthwest, showing a strong frequency peak in $240^{\circ}-270^{\circ}$. 


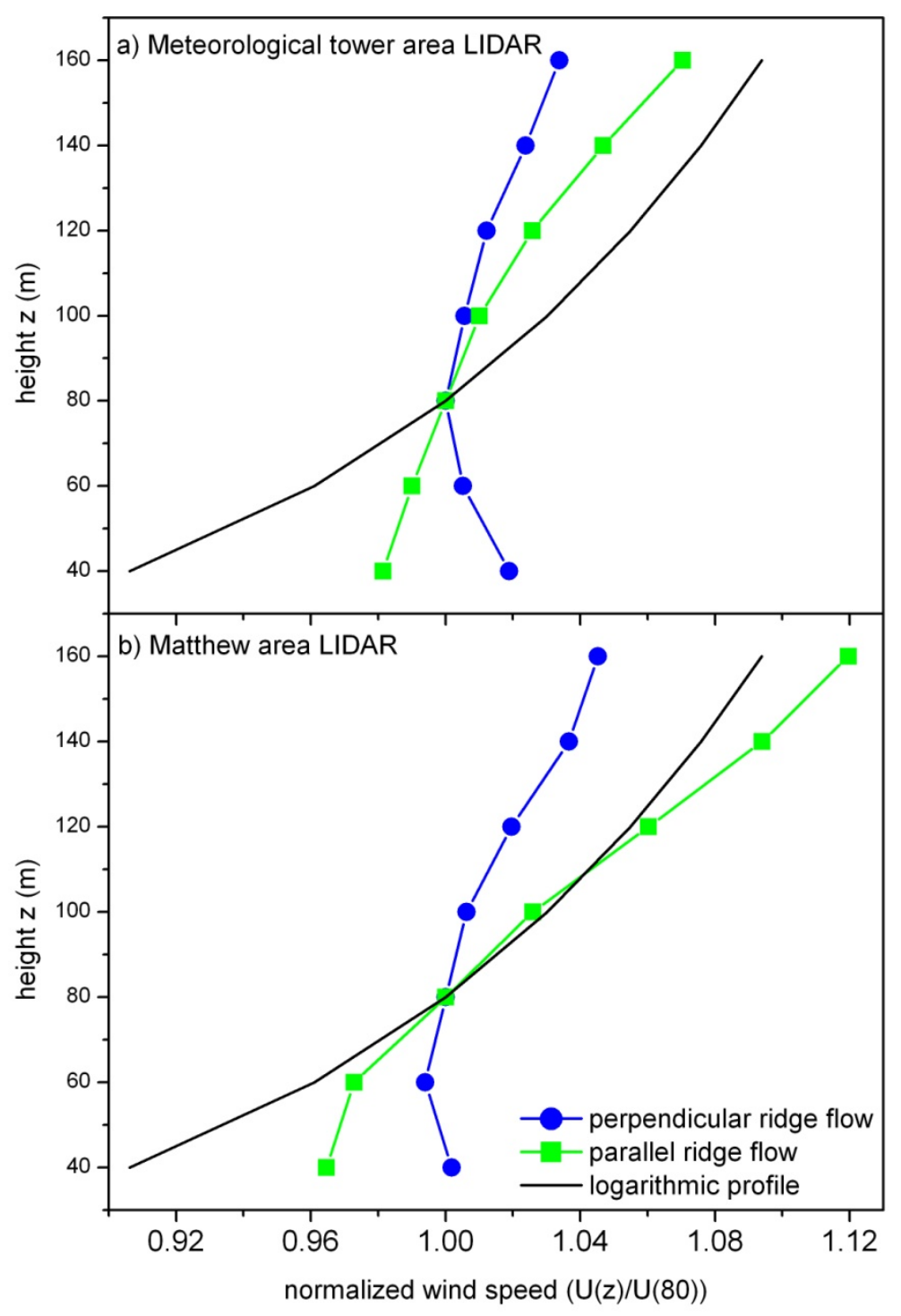

Figure 14: Normalized wind speed profiles from the LIDAR units at both locations during the March-April field campaign according to wind direction. Flows perpendicular to the ridge lines at the meteorological tower included the northeast and southwest directions while parallel ridge flow included the northwest and southeasterly directions. At the Matthew location, perpendicular ridge flow included wind from the northwest, north, east and west-southwest, while parallel ridge flow included the southeast to southwest sectors. 


\section{Offsite LIDAR field campaigns}

LLNL's LIDARs were utilized in two wind energy related projects in FY12. The first project included two field campaigns (winter and summer) at the Buena Vista wind farm in the Altamont Pass, California. Each campaign lasted two months and collected inflow wind speed, direction and turbulence measurements upwind of a row of $60 \mathrm{~m}$ tall, $1 \mathrm{MW}$ turbines. Figure 1 shows some of the data collected during the winter campaign at Buena Vista and the corresponding wind velocities measured at Site 300 (meteorological tower location) with the second LIDAR unit. Over the winter period, the average $80 \mathrm{~m}$ wind speed did not vary from location to location although there are magnitude differences apparent in the figure. Even though the LIDAR locations were separated by a distance of $18 \mathrm{~km}$, there is very little lag in the time series data indicating the presence of synoptic weather patterns dominating this time period. Data were also collected in April-August, 2012 in South Dakota for the Weather Forecast Improvement Project. In this field campaign, LLNL's LIDAR provided lower boundary layer wind measurements to augment NOAA's radar profiler system.

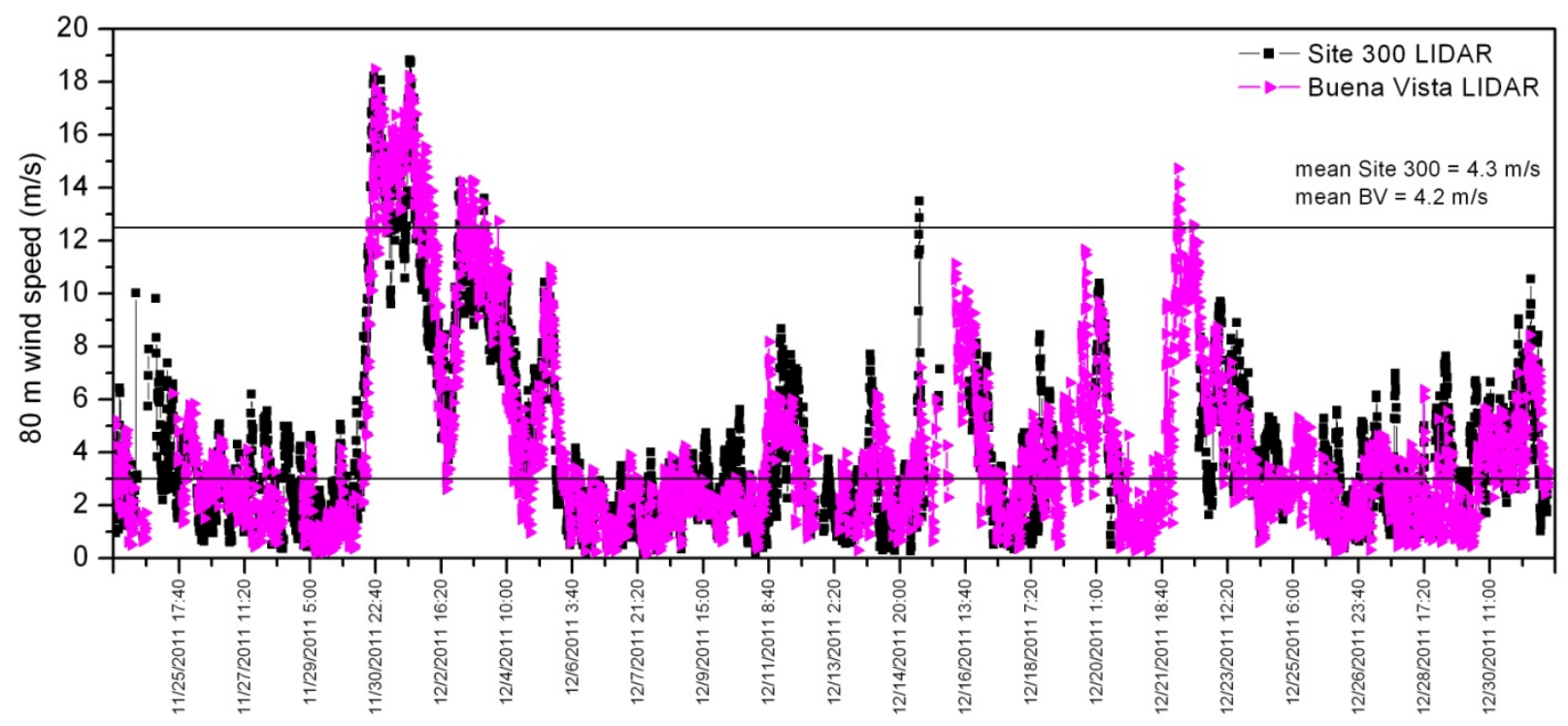

Figure 15: Time series plot of $80 \mathrm{~m}$ wind speed measurements at Site 300 and at the Buena Vista Wind Farm show high correlation between the timing of wind ramps and the average $80 \mathrm{~m}$ wind speed. Buena Vista is located $18 \mathrm{~km}$ to the north and is a $36 \mathrm{MW}$ wind farm. These data suggest that Site 300 has wind speeds comparable to the wind farm during the winter months.

LLNL's LIDAR was used for two spring campaigns in the Sierra Foothills of California and southern Washington State to study canopy flows over different vegetation types. The LIDAR was colocated with the Tonzi AmeriFlux tower in April 2012. In May 2012 the LIDAR was taken to Washington and co-located with the Wind River AmeriFlux tower. Both towers are part of the large Ameriflux tower network for studying biospheric sinks and sources of carbon dioxide and for quantifying water budgets over natural ecosystems. Tonzi is an oak savannah ecosystem and Wind River is a evergreen conifer, oldgrowth forest. The LIDARs measured wind speed, direction and turbulence over the plant canopies with the goal of understanding turbulent flow at times when the AmeriFlux towers largely underestimate carbon fluxes (due to a stable atmosphere at night). An example of the work is shown in Figure 16. 

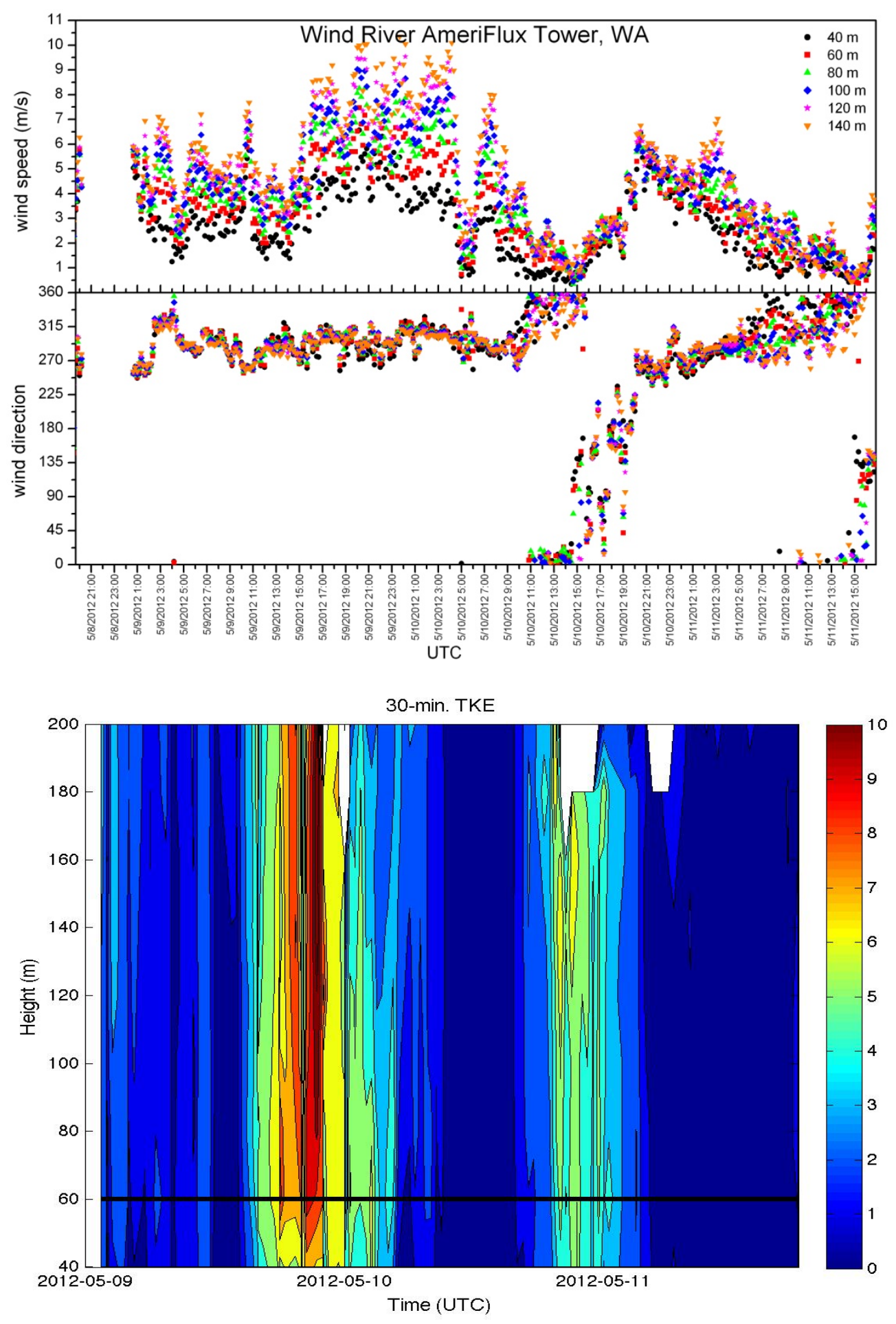

Figure 16: An example of data collected with LIDAR at the Wind River site. The project goal is to better understand turbulent structures above the canopy and to use this information to correct eddy covariance (EC) carbon fluxes when canopy-height turbulence is not well resolved by the single sonic anemometer at canopy height due to stable atmospheric conditions. The line drawn at $60 \mathrm{~m}$ represents the forest canopy height and height of the EC instrumentation. 